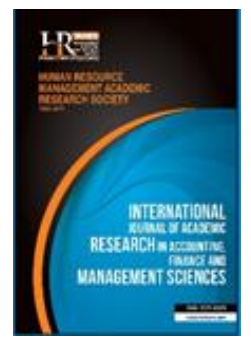

International Journal of Academic Research in Accounting, Finance and Management Sciences

Vol. 9, No.4, October 2019, pp. 126-143

E-ISSN: 2225-8329, P-ISSN: 2308-0337

(C) 2019 HRMARS

www.hrmars.com

To cite this article: Ayranci, E. (2019). Effects of Shared Leadership Perception on Perceived Intragroup Conflict: An Investigation in Technology Startups in Turkey, International Journal of Academic Research in Accounting, Finance and Management Sciences 9 (4): 126-143

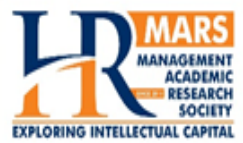

\title{
Effects of Shared Leadership Perception on Perceived Intragroup Conflict: An Investigation in Technology Startups in Turkey
}

\begin{abstract}
Evren Ayranci
Business Administration Department, Faculty of Economics and Administrative Sciences, Istanbul Kultur University, Halkali Merkez District, Basin Ekspres Street, No: 11, 34303 Kucukcekmece/Istanbul, Turkey,

E-mail: e.ayranci@iku.edu.tr
\end{abstract}

\begin{tabular}{|c|c|c|}
\hline Abstract & \multicolumn{2}{|c|}{$\begin{array}{l}\text { Though research about antecedents of competitiveness reveals many factors, a common ground appears to } \\
\text { be teamwork. Keeping this in mind, this study considers teamwork, but goes one step further by addressing } \\
\text { what lies beneath teamwork: collectivism. A review about collectivist notion in groups' points out that } \\
\text { intragroup conflict, and management and leadership are the two outstanding determinants of group } \\
\text { effectiveness. A further outcome from the review is that shared leadership is also emphasized within this } \\
\text { notion. Therefore, this study investigates if and how shared leadership perception is effective on perception } \\
\text { about intragroup conflict. The research, performed in technology startups in a techno park in the city of } \\
\text { istanbul, reveals noteworthy results. There is a similarity between the structures of perceived shared } \\
\text { leadership and intragroup conflict perception in the way that both emphasize their own formal and informal } \\
\text { components distinctively. The findings also prove that the participants' perceived intragroup conflict changes } \\
\text { based on their perception towards shared leadership. This change, nevertheless, is not fully possible when the } \\
\text { attention turns from the macro level to the factor level. }\end{array}$} \\
\hline Key words & \multicolumn{2}{|c|}{ Shared Leadership, Intragroup Conflict, Perception, Team, Turkey } \\
\hline Received: & 18 Dec 2019 & (C) The Authors 2019 \\
\hline Revised: & 02 Jan 2020 & Published by Human Resource Management Academic Research Society (www.hrmars.com) \\
\hline $\begin{array}{l}\text { Accepted: } \\
\text { Published Online: }\end{array}$ & $\begin{array}{l}05 \text { Jan } 2020 \\
09 \text { Jan } 2020\end{array}$ & $\begin{array}{l}\text { This article is published under the Creative Commons Attribution (CC BY 4.0) license. Anyone may } \\
\text { reproduce, distribute, translate and create derivative works of this article (for both commercial and } \\
\text { non-commercial purposes), subject to full attribution to the original publication and authors. The full } \\
\text { terms of this license may be seen at: http://creativecommons.org/licences/by/4.0/legalcode }\end{array}$ \\
\hline
\end{tabular}

\section{Introduction}

Though everything seems changeable in the contemporary business realm, there is one exception: competitiveness. This phenomenon is the main problem of various businesses, and moreover, it is a vital topic in a vast variety of scientific research. How to achieve and protect sustainable competitiveness is an indispensable part of the literature and many issues such as innovativeness (Lefebvre et al. 2000), dynamic capabilities (Martini et al. 2013), and process management (Zairi, 1997) are posited to be the key factors.

A review of these factors is the motivation behind this study. There is adequate evidence that effective teamwork as a result of collaborative collectivism is the underlying reason for all these mentioned factors (Hauschildt and Kirchmann, 2001; Kohlbacher, 2013), and therefore, the focal spot is collectivism. This spot is highlighted in countless studies in relation to various concepts (Husted and Allen, 2008), subjects (Li et al. 2000) and contexts (Mattila and Patterson 2004). There is, however, a shortcoming: although shared leadership (Wang et al., 2014) and intragroup conflict (Passos and Caetano, 2005) are considered as powerful determinants of team effectiveness through this collectivist notion, there is a gap regarding the inspection of these two subjects' interconnection. 
Therefore, this study seeks to explore this connection. There are claims in the literature that shared leadership could be used to regulate or even benefit from intragroup conflict for better team effectiveness (Kocolowski, 2010), and hence, this leadership paradigm is posited to be effective on intragroup conflict. This effect is checked in the current study along with the consideration that both leadership (Ford 2010) and conflict (Fuss et al. 2008) are mainly psycho-social aspects, and thus, are shaped by one's related perception. Therefore, perceived shared leadership and perceived intragroup conflict are taken into account and it is expected that the aforementioned conflict shows changes based on shared leadership perception. This expectation is not solely considered overall; there are also factor level effects anticipated.

Finally, the investigations are carried out via the data from the members of technology startups in a large techno park in Istanbul, Turkey due to the facts given in the literature that these organizations desperately need teamwork (Ulijn et al., 2011) and that they are prone to conflicts that need to be regulated by appropriate applications of management and leadership (Cho and McLean, 2008; Kaiser and Müller, 2013).

\section{Literature review}

\subsection{Shared Leadership: Importance, background and definitions}

The domain of leadership is full of theories, approaches, and definitions, and thus, a vast variety of scientific research. Among these, a curiosity for shared leadership is attention-taking. The literature posits that research about shared leadership is yet very primitive (Pearce and Conger, 2002) and there is a necessity to scrutinize this subject thoroughly for several reasons, all of which are related to advancements in business administration realm.

The historical view assumes that businesses must be considered as hierarchically formed and managed entities (Jones and Zeitlin, 2008), and that there is a central figure with the task of orienting and controlling the business (Booth and Rowlinson, 2006). This view is, however, confuted by and large currently due to increasing complexities. Technological changes (Dyerson and Mueller, 1999), need for specialization (Powell 2000), contingencies (Zaccaro et al., 2009), and environmental fluctuations (Inamizu et al., 2014) call for teamwork in any business. It is indeed possible to talk about various teams at management (Atılgan, 2017) and tasking (Chan et al., 2014) contexts.

The nature of teamwork involves distribution of duties in accordance with team members' unique features (Panzaru, 2014). As one might consider, the initial distribution could be made by a team leader (Pearce et al., 2009). During the performance of the team afterwards, there would be volatile or even unforeseen situations that could bring forth the needs for specific expertise. The expectation, in this case, would be an appropriate match between these needs and the most suitable team members (De Dreu and Weingart, 2003). In other words, the team leader is expected to make the initial distribution and any subsequent updates. However, the leader's role is not over yet; performing as a team implies collaboration based on the combination of each team member's unique features (Cogliser et al., 2012). This fact highlights the need of each team member for peers' own unique resources, which should also be coordinated by the leader (Zaccaro et al., 2001). Briefly, team leadership is essential for an effective teamwork bidirectionally; in terms of matching situations and team members' unique features dynamically and providing intragroup collaboration by means of matching these features correctly.

Nevertheless, an intriguing fact is the literature's general negligence of team members' own emerged leadership by means of emphasizing an appointed team leader (Kozlowski and Bell, 2003). Debates about this negligence have many grounds and generally stem from the very nature of teams. It is, for instance, posited that teams are in fact very complex structures involving perplexing interactions and the necessity of coordinating unique team member knowledge, experience and abilities; and thus, there could be shortcomings of leadership duties performed by a single appointed team leader (Day et al. 2004). Considering team members' uniqueness, it is also voiced that each team member could require a span of autonomy in order to use own unique features for tasking, which in turn, motivates each team member's contribution to team leadership practices (DeNisi et al., 2003). This last issue is not only addressed by the leadership paradigm, there is the emphasis of management field on the member uniqueness within the subject of self-managing teams (Wageman, 1997; Millikin et al., 2010). Therefore, there is ample evidence that team members' taking part in team direction is favored. 
A literature review to find out how this favor emerged and evolved brings forth an interesting outcome: it has indeed an old past. Rooting from the human relations approach, the need to understand employees has gradually been emphasized and eventually sharing has become a vital subject within many theories. A travel in history begins with the famous works of Mayo (1933) and Barnard (1938), who simultaneously voiced the idea that not only employees' financial, but also their psycho-social needs had to be taken into consideration in management process. After the uncovered truth that members of a group were inclined to assume different roles (Benne and Sheats, 1948), interactions between these members along with the conventional hierarchical management approach were simultaneously considered as scientific research foci (Homans, 1958). Existence of common goals, moreover, gave rise to an evolution of the idea about these interactions; all group members, including managers and employees, could participate in goal determination and performance (Drucker, 1954), which in turn, splashed to leadership paradigm. There were, for instance, claims that the leader should involve the members in decision-making processes depending on conditions (Vroom and Yetton, 1973); the need for a specific leader could vary according to the tasks at hand (Kerr and Jermier 1978) and furthermore, group members should be allowed to self-lead under specific conditions (Manz and Sims, 1980). Besides the general interest in the leader in relation to this power sharing and participation, the other side - followers - is another topic of scientific interest. Starting with empowerment (Conger and Kanungo, 1988), the extent to which followers were ready and motivated for a collaborative goal-setting process was an issue of research (Converse et al., 1993), with an extension towards the responsiveness of followers towards their leader's calls (Lipman-Blumen, 2000).

As could be noticed, this specific history does not directly address shared leadership; it is fundamentally on the grounds of shared thinking for leadership. A distinctive idea in history, on the other hand, encourages shared leadership in the primal form of co-leadership. Being a distinct paradigm, coleadership emphasizes only one leadership role, which is divided between two individuals simultaneously (Solomon et al., 1953). While 1960s saw the research about its applications (Mintz, 1963); this paradigm's emerge (Lester 1975) and effectiveness (Herzog 1981) were questioned thereafter. A very striking idiosyncrasy is the assumption that there is a rank difference between these two individuals in coleadership (Rittner and Hammons, 1993).

It is also noteworthy that the two subjects, shared leadership and co-leadership, emerged simultaneously in the literature. Like the case with co-leadership, the ever first scientific research directly referring to shared leadership date back to 1950s. Gibb (1954), for instance, is the first scholar to stress that the task of leadership for a given group should be shared by the group members. A consideration of this idea within the organizational context belongs to Katz and Kahn (1978), who conclude that the nature of this sharing should be scrutinized when teams in organizations are in question. Team members should assume leadership role voluntarily and at times, when they expect that their unique features could be of best interest to their shared team goals, and therefore, their organizations.

This view is widely accepted by recent studies, but they also make some additions or alterations. Day et al. (2004), for example, define shared leadership as the existence of collective effects among team members that emerge due to their voluntary actions and use of their unique features for better team and organizational performance. Pearce and Conger (2003) have a very similar consideration but they also posit that the dynamism of the team members' effects must also be accounted for. Pearce et al. (2004) follow the definition of Pearce and Conger (2003), and eke that the emerge of shared leaders may be in official or unofficial (contextually generated) terms. Confirming Pearce et al. (2004), Mehra et al. (2006) conclude that there may be simultaneous official and emergent leaders in each team. Whether official or unofficial, Ensley et al. (2006) make an expansion and determine the shared leadership to be a team process in which all team members assume the role of leadership simultaneously.

Despite these slight differences, the emphasis on teams and collectivism is profound and could be traced in many definitions. Examples involve the approach that belongs to Carson et al. (2007), who evaluate shared leadership as the distribution of leadership among team members and Bligh et al. (2006), who discuss it to be team members' collective assumption of the leadership role.

A straight implication from these definitions is that there are noteworthy differences between shared leadership and other leadership approaches. As the name suggests, shared leadership calls for a collectivist leadership behavior (Cox et al., 2003), whereas other approaches emphasize leader's singular initiative 
(Storey, 2004). This emphasis indispensably gives rise to a hierarchical structure (Storey, 2004) as opposed to the lateral connections of shared leadership (Pearce and Sims, 2002). The nature of collectivism reflects on member and team behaviors as expected; and therefore, members have the possibility of acting autonomously (Pearce and Sims, 2002) and teams facilitate from a consensus-based understanding for mobilization (Graham and Barter, 1999).

As aforementioned, the interest in shared leadership is still at an initial stage; and therefore, there is not an abundance of various related studies. Nevertheless, the existing research points out that shared leadership is studied in organizations such as banks (Walker et al., 2008), local governments (Berman, 1996), police stations (Steinheider and Wuestewald, 2008), churches (Wood and Fields, 2007), and manufacturing enterprises (Anderson et al., 2008) along within specific fields involving education (Rice 2006; Meyers and Johnson, 2008) and healthcare (Steinert et al., 2006; Konu and Viitanen, 2008), and within expert teams of sales (Mehra et al., 2006), maintenance (Hiller et al. 2006), and consulting (Carson et al., 2007). The general conclusion of these studies is that shared leadership is a beneficial issue for teams and organizations.

\subsection{Intragroup Conflict: Collectivist Approach and the Need for Leadership}

Being a very prominent subject, conflict and conflict-related issues draw a great deal of attention in the literature. This attention, as could be expected, partially belongs to the research regarding groups. The main research stream is towards intragroup conflicts and their effects on various group topics such as performance (Jehn and Bendersky, 2003), sustainability (Vancouver, 2000), and member contentment (Folger et al. 2001). There is also a consensus regarding the contexts of these conflicts: relationships (Jehn 1995), processes (Martínez-Moreno et al., 2009), and tasks (Amason and Sapienza, 1997) though there are opposing remarks (De Dreu and Weingart, 2003).

These remarks dwell on the fact that simultaneous intragroup conflicts could stem from multiple reasons (Schaeffner et al., 2015) and group dynamics, features, or processes could be very effective in these multi-faceted conflicts (Jehn, 1997; Simons and Peterson, 2000; de Wit et al., 2012). Therefore, analyzing and solving such a conflict structure require a collectivist approach. There is indeed ample finding that intragroup conflict management and resolution (Tjosvold, 1991), and problem-solving (Jehn and Mannix, 2001) require a collectivist notion, both of which give rise to a cooperative or a collaborative approach (Tse et al., 1994; De Dreu, 2006). This collectivist notion is so important that the harmony and conformity among group members are claimed to be more important than the common goal (Shenkar and Ronen, 1987) on the grounds that the continuity of a common sense could overarch this goal and determine the very existence of the group itself (Westwood et al. 1992), and the collectivism could promote open-mindedness while considering and arguing about conflict sources (De Dreu and van de Vliert, 1997). Efforts regarding the embodiment of this collectivism usually point out group norms and features. Groups with open, tolerant and harmonious norms (Jehn, 1997), conflict norms (Jehn et al., 1997), and fellowship ties (Shah and Jehn, 1993) have a better chance of overcoming or even benefiting from intragroup conflicts. Thus, it becomes possible to state the dual role of the collectivist approach; it is not only effective in conflict management and resolution, but it is also a possible agent of benefit due to its potentiality to extract value from intragroup conflicts.

According to some studies, a collectivist management paradigm is considered as a key to extract this value. Group managers have a vast variety of thinking patterns and the concordant reflection of these patterns is posited to create an environment for creativity that also enables a base for debates and communication among members in order to find out the best decisions (Eisenhardt and Schoonhoven, 1990). Although these debates could bring up intragroup conflicts (Simons et al., 1999), benefits of the final decisions taken, or the effectiveness achieved generally surpass the conflicts (De Dreu, 2006; de Wit et al., 2012). This ample evidence urges studies to find out the most suitable approaches to start valuable intragroup conflicts in order to maximize the potentiality to come up with the most beneficial outcomes (Jehn and Mannix, 2001; De Dreu and Weingart, 2003).

On the contrary, a part of the literature emphasizes the need for a collectivist leadership paradigm rather than a collectivist notion within the domain of management. The group members should be able to express their ideas and feelings directly (Weldon et al., 1996), communicate with each other easily (Barker 
et al., 1988), co-integrate their ideas (Garfield et al., 2001), and focus on mutual interests and the feeling of being a team player (Edwards and Peccei, 2007) in order to come up with positive or even beneficial outcomes regarding intragroup conflicts. Research about these necessities point out the requirement of specific leadership approaches that focus on listening to the group members (Foels et al., 2000), encouraging their participation in decision making processes (Wood and Fields, 2007), promulgating a sense of justice (Friedrich et al., 2009), considering team members' interactions (Prati et al., 2003) and providing empowerment (Chen et al., 2007).

The search for appropriate collectivist leadership approaches for groups generally leads to three specific ends: transformational, team, and shared leadership. To start with, there are various studies that prove positive effects of transformational leadership on group performance and these studies could be split up into two domains. While one of the domains considers the direct relationships between transformational leadership components and group performance measures (Dionne et al., 2004), the other emphasizes an indirect approach and prefers to use the transformational leader's conflict resolution capabilities in order to foster group performance (Hendel et al., 2005). This second domain profoundly outlines the adequacy of transformational leadership as a collectivist leadership approach for groups; this leader introduces shared goals and common interests (Lim and Ployhart, 2004), encourages collective identity and values to strengthen psychological group attachment (Bass 1985), points out that conflicts are mutual problems among the members and their resolution requires dialogue (Tjosvold, 2008), and passes judgment that the collectivist notion should be upheld in times of conflict in favor of the group goals and viability (Tyler and Blader, 2003).

Team leadership has many proponents due to the reason that team dynamics and diversities require interchangeable leadership behaviors beyond those of more conventional leadership practices (Klein et al., 2011). This leadership approach exhibits a more collectivist notion on the ground that it emphasizes the collaboration of team members' diversities (Mohammed and Nadkarni, 2011). The extent of this collaboration, surprisingly, is not to be maximized by the team leader; the leader could pose a more taskoriented behavior set in order to act on behalf of better team outcomes with a side effect: team members are restricted to assert their original values and ideas (Zaccaro et al., 2001). A further implication of this restriction is even more surprising; as team members are not generally able to expose their diversities, they not only fail to form a context of harmony, but they also fail to give rise to strong conflicts (Klein et al., 2011). This outcome, accompanied by some further evidence (Somech, 2006), show that team leadership's original focus is on diversity collaboration and therefore conflict could be considered as an instrument for team effectiveness.

Shared leadership is way ahead of team leadership in terms of emphasizing the importance of diversity collaboration. Accepting that diversities in groups should be considered at various levels and in contexts, shared leadership posits that effects of these diversities are not limited to the group level; they could directly affect organizational outcomes (Carson et al., 2007). Therefore, diversity management is a too delicate matter to be carried out by a single person (Horwitz, 2005), and diversities necessitate sharing members' mutual influences rather than posing the influence of a single leader (Carson et al., 2007). Despite the difference about consideration of diversities, shared and team leadership paradigms are parallel in terms of conflict; it is a double-edged sword that should be used for effectiveness (Hu et al., 2017). Research indeed point out that shared leadership is very effective in providing superior performance by manipulating conflicts (Perry et al., 1999; Sivasubramaniam et al., 2002), and it outperforms one-man leadership approaches when group work is questioned (Ensley et al., 2006).

\section{Methodology of research}

\subsection{Aim, sample, and data collection method}

As per literature's findings, it is expected that shared leadership would be effective on intragroup conflict. However, the nature of this effect is unknown yet, and moreover, there is no consensus regarding to this nature in the literature. Therefore, a contribution to the related array of research is expected. A catchy point is the collectivism when shared leadership and intragroup conflict are taken into account, and thus, it is decided that the participants should be team members in businesses. A final point is that both 
leadership (Bradley et al., 2006; Antonakis and Day, 2017) and conflict (Knutson et al., 2000; Tidd et al., 2004) are perceived subjects, which in turn, necessitates a scrutinization of these members' perception.

Combining all these facts, this research aims to find out if and to what extent team members' perceived intragroup conflict exhibits significant differences based on their shared leadership perception. The if part is to be tested by the analysis of the research hypothesis 1 :

$\mathrm{H}_{1}$ : Participants' perceived intragroup conflict exhibits significant differences based on their shared leadership perception.

The to what extent part, on the other hand, considers factor-level effects. In other words, perception about shared leadership and intragroup conflict are both expected to be composed of some factors, and hence, factor-level connections are expected. In line with the research hypothesis 1 , the extent of these connections is supposed to be full, as denoted in research hypothesis 2 :

$\mathrm{H}_{2}$ : All factors of participants' perceived intragroup conflict exhibit significant differences distinctively based on the participants' shared leadership perception factors.

A concomitant consideration of these two hypotheses implies the expectation of a sheer connection between these two subjects.

A very delicate method is followed to determine these team members. It is ultimately decided that technology startups should be pursued rather than other forms of organizations on two grounds. One of the reasons is the expectation about data collection limitations; different organizations could have various forms of teams and some of these may not be accessible, which could violate the intention of fully demonstrating teams in organizations. The other reason is linked with the features of technology startups. These are mostly small-sized organizational forms with a high level of direct social interactions among its members (Chen et al., 2007), a need for members' special expertise for technical (Van Hove, 2018) and financial (Ertuğrul Ayrancı, 2018) issues, and the notions of teams (Baum and Silverman, 2004; Hahn et al., 2014) and leadership (Kassicieh, 2011; Sharma, 2015) are evident.

For these reasons, all technology startups in Yıldız Technical University technopark are chosen (Yıldız Kuluçka, 2018) and all members of these 110 startups are requested to participate in the research. This request is made in two stages by a professional consulting firm. In the first stage, the firm e-mails these startups to get their members' consent for participation. After one week, employees of the firm visit these startups and tell more details about the research. The result is the acceptance of 91 startups with a total of 542 participants.

The same consulting firm collects data via further visits to each startup and a questionnaire, prepared by the author, is used. This questionnaire is composed of many instruments dedicated to perception of shared leadership and intragroup conflict. Shared leadership perception is captured via a reworded version of Shared Leadership Perception Survey used by Wood (2005). This instrument is originally developed by Porter-O'Grady and Wilson (1995) and Wood (2005) adds some items from Hiller's (2001) instrument. The other end, perceived intragroup conflict, is measured by reworded items of Jehn's (1995) Intragroup Conflict Scale. As the Turkish context is considered, all items of the instruments are strictly translated into Turkish and are further corrected by professional Turkish language instructors.

The research process is divided into two sections. The first section involves the pilot study to investigate the statistical structures and reliabilities of the instruments in order to fine-tune the questionnaires, whereas the second section scrutinizes possible effects of shared leadership perception on perception about intragroup conflict.

\subsection{Results of the pilot study}

The pilot study is performed using the data from 142 participants, who are omitted from further steps of the research process to avoid double-counting. Due to rewordings and translations performed on the items of the Shared Leadership Perception survey, it is decided that an explorative factor analysis should be run to see how its items are converged. The criteria for the analysis involve principal components analysis, varimax rotation and the suppression of items with factor loadings less than $|0.5|$. The results in Table 1 point out a two-factor structure with an aggregated $74.664 \%$ of total variance explained. The overall reliability level (as measured by Cronbach's alpha method) is 0.922 . 
Table 1. Statistical Structure and Reliabilities of Shared Leadership Perception Survey

\begin{tabular}{|l|c|c|}
\hline \multicolumn{1}{|c|}{ KMO: 0.863. (Bartlett's test value is statistically significant at 5\%). } & $\begin{array}{c}\text { Collective } \\
\text { Decision-Making }\end{array}$ & Collaboration \\
\hline Variance Explained (\%) & $\mathbf{4 1 . 8 7 1}$ & $\mathbf{3 2 . 7 9 3}$ \\
\hline Cronbach's Alpha Value & $\mathbf{0 . 9 3 3}$ & $\mathbf{0 . 8 5 7}$ \\
\hline Each team member shares in establishing the goals for this organization. & 0.912 & 0.905 \\
\hline Each team member helps to frame the vision for this organization. & 0.893 & \\
\hline $\begin{array}{l}\text { Each team member has a say in deciding how resources are allocated in regard to the team's } \\
\text { priorities. }\end{array}$ & 0.824 \\
\hline $\begin{array}{l}\text { Each team member shares in deciding on the best course of action when a problem faces the } \\
\text { team. }\end{array}$ & 0.817 \\
\hline $\begin{array}{l}\text { The opinion of each team member counts when they share their perceptions regarding a } \\
\text { situation facing the team. }\end{array}$ & 0.783 & \\
\hline \begin{tabular}{l} 
Each team member helps to identify, diagnose, and resolve the problems that face this team. \\
\hline Team members collaborate with one another in making decisions that affect this organization.
\end{tabular} & & 0.884 \\
\hline $\begin{array}{l}\text { Each team member shares information with others on the team so that all members can work } \\
\text { more effectively. }\end{array}$ & 0.764 \\
\hline $\begin{array}{l}\text { Despite the job "titles" used within this organization, each team member is considered an } \\
\text { "equal" to the others on this team. }\end{array}$ & & 0.722 \\
\hline \begin{tabular}{l} 
A relational and vocational connection exists among members of this team. \\
\hline $\begin{array}{l}\text { Each team member is informally evaluated by, and is accountable to, all other members of this } \\
\text { team. }\end{array}$
\end{tabular} & & 0.696 \\
\hline
\end{tabular}

Please notice that the items have been reworded and been originally translated into Turkish during data collection.

The two factors from Table 1 pinpoint the essentials of the shared leadership; a collectivist approach while determining the organizational goals and vision, participation in many issues such as resource allocation, problem solving and taking action, and collaboration in terms of decision making, information sharing, equality perceptions and accountability. It could also be stated that the collectivist approach, with its references to deciding over many issues, reflects the formal face of teams; while the collaboration component is prone to the informal aspects as this component shows the expectations about team members' harmony in good faith. Results of the similar analyses for Intragroup Conflict Scale are given in Table 2, showing that there is again a two-factor construct with an overall $69.229 \%$ of variance explained. The reliability level is 0.826 .

Table 2. Statistical Structure and Reliabilities of Intragroup Conflict Scale

KMO: 0.711. (Bartlett's test value is statistically significant at $5 \%$ ).

There is a great deal of tension among the members of my team during decision making.

There is a great deal of personal friction among the members of my team during decision making.

There is a great deal of emotional conflict among the members of my team.

There are evident personality clashes among the members of my team.

There is a great deal of anger among the members of my team.

There is a great deal of disagreement among the members of my team over decisions on the table.

There are many disagreements over different ideas in my team.

My team must work through various differences of approaches about decisions.

There are many differences of opinions in my team about taking action. 30.548

\begin{tabular}{|c|c|}
\hline $\mathbf{3 8 . 6 8 1}$ & $\mathbf{3 0 . 5 4 8}$ \\
\hline $\mathbf{0 . 8 5 7}$ & $\mathbf{0 . 7 6 2}$ \\
\hline & \\
& \\
0.876 & \\
\hline 0.862 & \\
\hline 0.799 & \\
\hline 0.767 & \\
\hline & 0.822 \\
\hline & 0.803 \\
\hline & 0.789 \\
\hline
\end{tabular}

Please notice that the items have been reworded and been originally translated into Turkish during data collection. 
A clear finding from Table 2 is that the perceived intragroup conflict is a bi-fold issue and involves relational and task-related conflict components. While the perceived relational conflict component emphasizes tensions and personal frictions during deciding and refers to negative emotions and interactions; perceived task-related conflict highlights disagreements during decision-making and towards the variety of ideas, along with the stress that there are many different opinions and approaches regarding decisions. An aggregated outcome of the pilot study is that the instruments used reveal some structural changes when compared to their prior forms. Although the Shared Leadership Perception Survey is posited to be composed of 19 items grouped under four factors (Wood 2005); the current research finds out that the participants consider only 11 items divided into two dimensions, namely Collective Decision-Making and Collaboration. A comparison with Wood (2005) yields that the current participants strongly regard the mechanism of decision-making and the nature of collaboration rather than the prior study's claim on issues such as emotional support or mutual skill development. It is noted, on the other hand, that the current participants agree with the Jehn's (1995) Intragroup Conflict Scale; and thus, claim that their perception of intragroup conflict stem from relationships and tasks.

\subsection{Main Study: Effects of Shared Leadership Perception on Perceived Intragroup Conflict}

The last section of the research process seeks to find out facts about the research aim; if and how the participants' perception about shared leadership affect their perception regarding intragroup conflict. This section involves the analysis of data collected by the refined questionnaires from rest of the participants, 400 people. Due to the research aim and its accompanying hypotheses, it is decided that General Linear Models (GLMs) should be used to make the necessary analyses. These models are run at two different levels: the factor level and the overall level. Of these, the factor level models analyze any possible effects of shared leadership perception's two factors on the factors of perceived intragroup conflict distinctively. Therefore, these models consider micro level effects. The overall model, as the name suggests, overarches the factors and considers the macro (total) effect of shared leadership perception on perceived intragroup conflict.

\subsubsection{Results about Factor Level Effects}

The first GLM investigates the effects of shared leadership perception factors on the perceived relational conflict. The results given in Table 3 point out a partial effect. 
Table 3. Results of the Multivariate Model of the Collective Decision-Making and Collaboration's Effects on the Perceived Relational Conflict

\begin{tabular}{|c|c|c|c|c|c|c|c|c|c|}
\hline \multicolumn{10}{|c|}{ Multivariate Tests $^{\mathrm{a}}$} \\
\hline \multicolumn{2}{|l|}{ Effect } & Value & $\mathbf{F}$ & $\begin{array}{l}\text { Hypothesis } \\
\text { df }\end{array}$ & Error df & Sig. & $\begin{array}{l}\text { Partial } \\
\text { eta }^{2}\end{array}$ & $\begin{array}{l}\text { Noncent. } \\
\text { Parameter }\end{array}$ & $\begin{array}{l}\text { Observed } \\
\text { Power }^{\text {b }}\end{array}$ \\
\hline \multirow{4}{*}{ Intercept } & Pillai's trace & .953 & $3850,005^{c}$ & 2.000 & 381.000 & .000 & .953 & 7700.011 & 1.000 \\
\hline & Wilks' lambda & .047 & $3850,005^{c}$ & 2.000 & 381.000 & .000 & .953 & 7700.011 & 1.000 \\
\hline & $\begin{array}{l}\text { Hotelling's } \\
\text { trace }\end{array}$ & 20.210 & $3850,005^{c}$ & 2.000 & 381.000 & .000 & .953 & 7700.011 & 1.000 \\
\hline & $\begin{array}{ll}\text { Roy's largest } \\
\text { root }\end{array}$ & 20.210 & $3850,005^{c}$ & 2.000 & 381.000 & .000 & .953 & 7700.011 & 1.000 \\
\hline \multirow{4}{*}{$\begin{array}{l}\text { Collective } \\
\text { Decision- } \\
\text { Making }\end{array}$} & Pillai's trace & .077 & 5.125 & 6.000 & 764.000 & .000 & .039 & 30.747 & .994 \\
\hline & Wilks' lambda & .924 & $5.143^{c}$ & 6.000 & 762.000 & .000 & .039 & 30.856 & .995 \\
\hline & $\begin{array}{l}\text { Hotelling's } \\
\text { trace }\end{array}$ & .081 & 5.161 & 6.000 & 760.000 & .000 & .039 & 30.964 & .995 \\
\hline & $\begin{array}{l}\text { Roy's largest } \\
\text { root }\end{array}$ & .063 & $8.084^{d}$ & 3.000 & 382.000 & .000 & .048 & 24.253 & .991 \\
\hline \multirow{4}{*}{ Collaboration } & Pillai's trace & .047 & 1.472 & 12.000 & 736.000 & .129 & .023 & 17.670 & .802 \\
\hline & Wilks' lambda & .954 & $1.472^{c}$ & 12.000 & 734.000 & .129 & .023 & 17.662 & .802 \\
\hline & $\begin{array}{l}\text { Hotelling's } \\
\text { trace }\end{array}$ & .048 & 1.471 & 12.000 & 732.000 & .130 & .024 & 17.655 & .802 \\
\hline & $\begin{array}{l}\text { Roy's largest } \\
\text { root }\end{array}$ & .035 & $2.133^{\mathrm{d}}$ & 6.000 & 368.000 & .049 & .034 & 12.797 & .762 \\
\hline \multicolumn{10}{|c|}{ Box's $M^{d}=9.952(F=1.482 ;$ sig.= .180$)$ df1: $6.000 ;$ df2: 1818} \\
\hline \multicolumn{10}{|c|}{ a. Design: Intercept + Collective Decision-Making + Collaboration } \\
\hline \multicolumn{10}{|c|}{ b. Computed using alpha $=.05$} \\
\hline \multicolumn{10}{|c|}{ c. Exact statistic } \\
\hline \multicolumn{10}{|c|}{ d. The statistic is an upper bound on $\mathrm{F}$ that yields a lower bound on the significance level } \\
\hline
\end{tabular}

Table 3 signifies that the collective decision-making component of shared leadership perception is effective on the perceived relational conflict, albeit there is no such connection when the collaboration component is assumed to affect this conflict perception. An implication, therefore, is that the participants underline the decision-making process as a mark for relational negativities. In other words, they posit that deciding collectively about the goals, vision, resource allocation, troubleshooting, and acting are effective issues on their perception about relational conflict. When the issue is collaboration, on the contrary, there are not any effects on the perception about relational conflict; the participants assume that their harmony for deciding, sharing, equal treatment, and liabilities to each other are not any means to alter their relational conflict.

The results obtained from Table 3 seem to be astonishing. The content of the perceived relational conflict refers to strains and discrepancies during decision-making process, and therefore, it is natural to end up with connections with the collective decision-making component. Nevertheless, this conflict perception also involves the participants' adverse emotions towards their teammates along with negative interactions and it is intriguing to see that these embedded issues fail to act as agents of connection with the collaboration component of shared leadership perception. Thus, the participants insist that they perceive to have relational problems with their teammates only if the formal issue of decision-making is on the table. For informal issues - helping, sharing, equal considering, and accompting - there are no interpersonal negativities considered. Remembering that the participants are the members of technology startups, it could be concluded that they are highly sensitive to the success of their startups as they are inclined to come forward during collective deciding at the cost of unfavorable interactions and emotions.

The partial effect evident in Table 3 incites curiosity over the next analysis results. The second GLM considers the effects of the two shared leadership perception components on the other perceived intragroup conflict factor: perceived task-related conflict. A check with Table 4 reveals that there are statistically significant effects altogether this time. 
Table 4. Results of the Multivariate Model of the Collective Decision-Making and Collaboration's Effects on the Perceived Task-Related Conflict

\begin{tabular}{|c|c|c|c|c|c|c|c|c|c|}
\hline \multicolumn{10}{|c|}{ Multivariate Tests ${ }^{a}$} \\
\hline \multicolumn{2}{|c|}{ Effect } & Value & $\mathbf{F}$ & $\begin{array}{l}\text { Hypothesis } \\
\text { df }\end{array}$ & Error df & Sig. & $\begin{array}{l}\text { Partial } \\
\text { eta }^{2}\end{array}$ & $\begin{array}{l}\text { Noncent. } \\
\text { Parameter }\end{array}$ & $\begin{array}{c}\text { Observed } \\
\text { Powerb }\end{array}$ \\
\hline \multirow{4}{*}{ Intercept } & Pillai's trace & .923 & $2324.938^{c}$ & 2.000 & 390.000 & .000 & .923 & 4649.877 & 1.000 \\
\hline & $\begin{array}{l}\text { Wilks' } \\
\text { lambda }\end{array}$ & .077 & $2324.938^{c}$ & 2.000 & 390.000 & .000 & .923 & 4649.877 & 1.000 \\
\hline & $\begin{array}{l}\text { Hotelling's } \\
\text { trace }\end{array}$ & $\begin{array}{c}11.92 \\
3\end{array}$ & $2324.938^{c}$ & 2.000 & 390.000 & .000 & .923 & 4649.877 & 1.000 \\
\hline & $\begin{array}{l}\text { Roy's largest } \\
\text { root }\end{array}$ & $\begin{array}{c}11.92 \\
3\end{array}$ & $2324.938^{c}$ & 2.000 & 390.000 & .000 & .923 & 4649.877 & 1.000 \\
\hline \multirow{4}{*}{$\begin{array}{l}\text { Collective } \\
\text { Decision-Making }\end{array}$} & Pillai's trace & .059 & 2.305 & 10.000 & 758.000 & .011 & .030 & 23.054 & .933 \\
\hline & $\begin{array}{l}\text { Wilks' } \\
\text { lambda }\end{array}$ & .942 & $2.300^{c}$ & 10.000 & 756.000 & .012 & .030 & 23.002 & .932 \\
\hline & $\begin{array}{l}\text { Hotelling's } \\
\text { trace }\end{array}$ & .061 & 2.295 & 10.000 & 754.000 & .012 & .030 & 22.949 & .931 \\
\hline & $\begin{array}{l}\text { Roy's largest } \\
\text { root }\end{array}$ & .035 & $2.671^{d}$ & 5.000 & 379.000 & .022 & .034 & 13.355 & .812 \\
\hline \multirow{4}{*}{ Collaboration } & Pillai's trace & .065 & 3.264 & 8.000 & 782.000 & .001 & .032 & 26.114 & .973 \\
\hline & $\begin{array}{l}\text { Wilks' } \\
\text { lambda }\end{array}$ & .936 & $3.263^{c}$ & 8.000 & 780.000 & .001 & .032 & 26.102 & .973 \\
\hline & $\begin{array}{l}\text { Hotelling's } \\
\text { trace }\end{array}$ & .067 & 3.261 & 8.000 & 778.000 & .001 & .032 & 26.090 & .973 \\
\hline & $\begin{array}{l}\text { Roy's largest } \\
\text { root }\end{array}$ & .046 & $4.457^{d}$ & 4.000 & 391.000 & .002 & .044 & 17.828 & .938 \\
\hline \multicolumn{10}{|c|}{ Box's $M^{d}=30.235(F=1.424 ;$ sig.= 094$)$ df1: 21.000; df2: 9046} \\
\hline \multicolumn{10}{|c|}{ a. Design: Intercept + Collective Decision-Making + Collaboration } \\
\hline \multicolumn{10}{|c|}{ b. Computed using alpha $=.05$} \\
\hline \multicolumn{10}{|l|}{ c. Exact statistic } \\
\hline \multicolumn{10}{|c|}{ d. The statistic is an upper bound on $\mathrm{F}$ that yields a lower bound on the significance level } \\
\hline
\end{tabular}

The effects denoted in Table 4 point out that the participants consider both collective decisionmaking and collaboration to be the factors that could pose changes on their perception about task-related conflict. Connection between collective decision-making and this perceived conflict component is much expected as this component heavily refers to conflicts arising from diversities of opinions and approaches, as well as disagreements whilst deciding. The other connection, that is between collaboration and this perceived conflict issue, is also anticipated; the participants' extent of playing along with their teammates is effective on their perception that conflict could stem from the variety of opinions, approaches, and disagreements. The current outcomes give rise to a similar conclusion to that of Table 3; the participants must be very focused on their startups' success, as it is clear that the emphasis on their task-related conflict perception reveals the effects of both the formal (collective decision-making) and the informal (collaboration) factors of the shared leadership perception.

As already mentioned, the factor level effects are considered in research hypothesis 2 , which has the claim that the two factors of shared leadership perception are fully effective on the intragroup conflict perception factors distinctively. Despite these two factors' effects on perceived task-related conflict component (Table 4), one of the factors (collaboration) fails to pose an effect on perceived relational conflict (Table 3). Therefore, it is not possible to talk about a full effect of the two shared leadership perception factors on the components of intragroup conflict perception distinctively. In this case, the research hypothesis 2;

$\mathrm{H}_{2}$ : All factors of participants' perceived intragroup conflict exhibit significant differences distinctively based on the participants' shared leadership perception factors, is rejected.

\subsubsection{Result about Macro Effect}

The rejection of the hypothesis denoting factor level effects arouses curiosity towards the test of the first hypothesis, which posits that the perception about shared leadership is able to affect perceived 
intragroup conflict on the whole. In this case, there is an expectancy that there could be a full monolithic effect on the macro scale though this is not the case at the factor level. The results of the last GLM that uses the data of all items involved are given in Table 5.

Table 5. Results of the Univariate Model of the Shared Leadership Perception's Effect on the Perceived Intragroup Conflict

\begin{tabular}{|c|c|c|c|c|c|c|c|c|}
\hline \multicolumn{9}{|c|}{ Dependent Variable: Perceived Intragroup Conflict } \\
\hline Source & $\begin{array}{c}\text { Type III Sum of } \\
\text { Squares }\end{array}$ & df & $\begin{array}{l}\text { Mean } \\
\text { Square }\end{array}$ & $\mathbf{F}$ & Sig. & Partial Eta ${ }^{2}$ & $\begin{array}{l}\text { Noncent. } \\
\text { Parameter }\end{array}$ & $\begin{array}{c}\text { Observed } \\
\text { Power }\end{array}$ \\
\hline Corrected Model & $80.149^{a}$ & 3 & 26.716 & 84.984 & .000 & .392 & 254.951 & 1.000 \\
\hline Intercept & 3089.112 & 1 & 3089.112 & 9826.334 & .000 & .961 & 9826.334 & 1.000 \\
\hline Shared Leadership Perception & 80.149 & 3 & 26.716 & 84.984 & .001 & .392 & 254.951 & 1.000 \\
\hline Error & 124.491 & 396 & .314 & & & & & \\
\hline Total & 5920.000 & 400 & & & & & & \\
\hline Corrected Total & 204.640 & 399 & & & & & & \\
\hline \multicolumn{9}{|c|}{ a. R Squared $=.392$ (Adjusted R Squared $=.387$ ) } \\
\hline \multicolumn{9}{|l|}{ b. Computed using alpha $=.05$} \\
\hline \multicolumn{9}{|c|}{ Levene's test of equality of error variances (Design: Intercept + Shared Leadership Perception) } \\
\hline
\end{tabular}

Table 5 indisputably shows that the participants' perception about shared leadership is indeed effective on their perception regarding intragroup conflict. As per this finding, research hypothesis 1;

$\mathrm{H}_{1}$ : Participants' perceived intragroup conflict exhibits significant differences based on their shared leadership perception, is accepted.

\section{Conclusions and Recommendations}

Contemporary business environment calls for teamwork on behalf of effectiveness. While this call is also made by the literature, it is noted that the success of teamwork is a continuum between intragroup collaboration and conflict. The tradeoff between these two issues gets interesting as there is proof that both could simultaneously be used as tools for effectiveness. Further investigations of the literature, moreover, reveal that the key to both issues is collectivism and this key could be used by the shared leadership paradigm. In other words, this leadership paradigm assumes collectivism as an underlying mechanism to regulate and even benefit from the mentioned collaboration and conflict. Considering all these facts, the current study explores perceptions regarding the shared leadership, collectivism, and the conflict. The expectations are that this leadership involves a peripheral approach for collectivism, and it relates to the conflict. Data, gathered from the members of technology startups in a prominent technopark in İstanbul, Turkey are analyzed, and the mentioned expectations are fulfilled. The shared leadership perception, first, is built on a collectivist notion that refers to collaboration and collective decision-making simultaneously. The contents of these two factors, furthermore, reveal that the decision-making refers to formal issues such as setting up organizational goals and vision, a collective contribution for resource allocation judgments, and participation in the discussion and solution steps of problems; whereas the collaboration is about an informal harmony towards information sharing, deciding, equality, and accountability. In this case, the expectation about collectivism is met.

The other end, perception about intragroup conflict poses a similar structure to that of shared leadership perception in terms of combining formal and informal issues altogether. The perceived taskrelated conflict component mainly refers to formal (mechanistic) negativities such as disagreements, and excessive varieties of ideas and approaches emerged during decision-making. The perceived relational conflict, on the contrary, addresses informal unfavorableness heavily and thus emphasizes tensions, interpersonal disputes, and negative emotions and interactions.

The part of the prementioned expectation that targets the existence of a relationship is also met. The participants clearly posit that their perception regarding intragroup conflict exhibits significant differences based on their perception towards shared leadership. In other words, they claim that the collectivist nature of shared leadership gives rise to changes in how they perceive clashes within their groups. This outcome acknowledges the results achieved in the literature and signifies the potential role of this leadership paradigm on various group dynamics, conflict being in the spotlight in this particular study. 
Despite this outcome, the shift from the macro perspective to the factor level reveals different findings, and hence, leads to some specific implications. Both components of the shared leadership perception can fully affect the perceived task-related conflict; suggesting that the participants are very delicate about their tasks and decision-making, they are prone to have conflicts regarding these issues, and therefore consider that both formal and informal aspects of the shared leadership are essential moderators of this type of conflict perception. If the attention turns to the other conflict factor, the perceived relational conflict, then the informal shared leadership perception component - collaboration - is not effective anymore. Remembering that this conflict component has informal contents, it is amusing to see that there is no leadership-conflict perception tradeoff once informality is taken into account. A possible implication is the idea of the participants that their interpersonal clashes relate to issues other than the extent of their intentions to act in harmony. This possible implication leads to the consideration of a follow-up implication; the participants prioritize collective decision-making processes over how they get on with their teammates.

This study agrees with the literature on the existence of the leadership's effect on the conflict via the macro perspective, i.e., when shared leadership and intragroup conflict perceptions are assumed to be monolithic issues; nevertheless, a consideration of the distinct conflict factors yields that this effect is partly achieved. A convenient recommendation for future research, in this case, is to perform further investigations at the macro and factor levels simultaneously in order to account for any variations that may occur within the leadership-conflict relationships. A second recommendation that could precede this one is about measurement; there seem to be an abundance of research for shared leadership and intragroup conflict, albeit there is a scarcity in the development of peripheral measurement instruments that are widely validated. This scarcity may be addressed in future research and the instruments could be enriched by the addition of many person-specific issues such as culture and personality, group-specific issues such as size and task distribution, and organization-specific issues involving the goals, vision, and sector. A third recommendation overarches the business context; and thus, suggests using data from many other settings such as sports, education, politics, and military while investigating the relationship. Finally, all investigations could be carried out in multiple settings or multiple teams within the same setting simultaneously and results could be compared. Thus, the relationship scrutinized in this study has a great potential to be considered in more details by future research.

\section{References}

1. Amason, A. C., \& Sapienza, H. J. (1997). The effects of top management team size and interaction norms on cognitive and affective conflict. Journal of Management, 23(4), 495-516.

2. Anderson, M. C., Anderson, D. L., \& Mayo, W. D. (2008). Team coaching helps a leadership team drive cultural change at Caterpillar. Global Business and Organizational Excellence, 27(4), 40-50.

3. Antonakis, J., \& Day, D. V. (2017). The nature of leadership. California: Sage Publications.

4. Atılgan, Ö. (2017). The relationship between job satisfaction and work performance: a research on the academicians (In Turkish). Kafkas University Journal of Economics and Administrative Sciences Faculty, $8(15), 35-55$.

5. Barker, J., Tjosvold, D., \& Andrews, I. R. (1988). Conflict approaches of effective and ineffective project managers: a field study in a matrix organization. Journal of Management Studies, 25(2), 167-178.

6. Barnard, C. I. (1938). The functions of the executive. Cambridge, MA: Harvard University Press.

7. Bass, B. (1985). Leadership and performance beyond expectation. New York, NY: Free Press.

8. Baum, J. A. C., \& Silverman, B. S. (2004). Picking winners or building them? Alliance, intellectual, and human capital as selection criteria in venture financing and performance of biotechnology startups. Journal of Business Venturing, 19(3), 411-436.

9. Benne, K. D., \& Sheats, P. (1948). Functional roles of group members. Journal of Social Issues, 4(2), 41-49.

10.Berman, E. M. (1996). Local government and community-based strategies: evidence from a national survey of a social problem. The American Review of Public Administration, 26(1), 71-91.

11.Bligh, M. C., Pearce, C. L., \& Kohles, J. C. (2006). The importance of self-and shared leadership in team based knowledge work. Journal of Managerial Psychology, 21(4), 296-318. 
12.Booth, C., \& Rowlinson, M. (2006). Management and organizational history: prospects. Management \& Organizational History, 1(1), 5-30.

13.Bradley, T. P., Allen, J. M., Hamilton, S., \& Filgo, S. K. (2006). Leadership perception. Performance Improvement Quarterly, 19(1), 7-23.

14.Carson, J. B., Tesluk, P. E., \& Marrone, J. A. (2007). Shared leadership in teams: an investigation of antecedent conditions and performance. Academy of Management Journal, 50(5), 1217-1234.

15.Chan, T. Y., Li, J., \& Pierce, L. (2014). Compensation and peer effects in competing sales teams. Management Science, 60(8), 1965-1984.

16.Chen, G., Kirkman, B. L., Kanfer, R., Allen, D., \& Rosen, B. (2007). A multilevel study of leadership, empowerment, and performance in teams. Journal of Applied Psychology, 92(2), 331-346.

17.Cho, Y., \& McLean, G. N. (2008). IT companies HR practices in South Korea. Asia-Pacific Collaborative Education Journal, 4(1), 49-64.

18.Cogliser, C. C., Gardner, W. L., Gavin, M. B., \& Broberg, J. C. (2012). Big five personality factors and leader emergence in virtual teams: relationships with team trustworthiness, member performance contributions, and team performance. Group and Organization Management, 37(6), 752-784.

19.Conger, J. A., \& Kanungo, R. N. (1988). The empowerment process: integrating theory and practice. Academy of Management Review, 13(3), 471-482.

20.Converse, S., Cannon-Bowers, J. A., \& Salas, E. (1993). Shared mental models in expert team decision making. In N. J. Castellan (Ed.), Individual and group decision making (pp. 221-245). Mahwah: Lawrence Erlbaum Associates.

21.Cox, J. F., Pearce, C. L., \& Sims, J., H. P. (2003). Toward a broader agenda for leadership development: extending the traditional transactional-transformational duality by developing directive, empowering and shared leadership skills. In R. E. Riggio and S. Murphy (Eds.), The future of leadership development (pp. 161-179). Mahwah, NJ: Lawrence Earlbaum.

22.Day, D. V., Gronn, P., \& Salas, E. (2004). Leadership capacity in teams. The Leadership Quarterly, 15(6), 857-880.

23.Dreu, D. C., \& Vliert, V. D. E. (1997). Using conflict in organizations. Beverly Hills, CA: Sage.

24.Dreu, D. C. K. W. (2006). When too little or too much hurts: evidence for a curvilinear relationship between task conflict and innovation in teams. Journal of Management, 32(1), 83-107.

25.Dreu, D. C. K. W., \& Weingart, L. R. (2003). Task versus relationship conflict, team performance, and team member satisfaction: a meta-analysis. Journal of Applied Psychology, 88(4), 741-749.

26.De Wit, F. R. C., Greer, L. L., \& Jehn, K. A. (2012). The paradox of intragroup conflict: a metaanalysis. Journal of Applied Psychology, 97(2), 360-390.

27.DeNisi, A. S., Hitt, M. A., \& Jackson, S. E. (2003). The knowledge-based approach to sustainable competitive advantage. In S. E. Jackson, M. A. Hitt, \& A. S. DeNisi (Eds.), Managing knowledge for sustained competitive advantage (pp. 3-33). San Francisco: Jossey-Bass.

28.Dionne, S. D., Yammarino, F. J., Atwater, L. E., \& Spangler, W. D. (2004). Transformational leadership and team performance. Journal of Organizational Change Management, 17(2), 177-193.

29.Drucker, P. F. (1954). The practice of management. New York, NY: Harper \& Row.

30.Dyerson, R., \& Mueller, F. U. (1999). Learning, teamwork and appropriability: managing technological change in the department of social security. Journal of Management Studies, 36(5), 629-652.

31.Edwards, M. R., \& Peccei, R. (2007). Organizational identification: development and testing of a conceptually grounded measure. European Journal of Work and Organizational Psychology, 16(1), 25-57.

32.Eisenhardt, K. M., \& Schoonhoven, C. B. (1990). Organizational growth: linking founding team, strategy, environment, and growth among U.S. semiconductor ventures, 1978-1988. Administrative Science Quarterly, 35(3), 504-529.

33.Ensley, M. D., Hmieleski, K. M., \& Pearce, C. L. (2006). The importance of vertical and shared leadership within new venture top management teams: implications for the performance of startups. The Leadership Quarterly, 17(3), 217-231.

34.Ertuğrul Ayrancı, A. (2018). New financing perspectives in terms of innovative entrepreneurship (In Turkish). In E. Ayrancı (Ed.), Innovativeness and entrepreneurship: approaches based on management, marketing and finance (In Turkish) (pp. 187-213). İstanbul, Turkey: Beta Publications. 
35.Foels, R., Driskell, J. E., Mullen, B., \& Salas, E. (2000). The effects of democratic leadership on group member satisfaction: an integration. Small Group Research, 31(6), 676-701.

36.Folger, J., Poole, M., \& Stutman, R. (2001). Working through conflict: strategies for relationships, groups, and organizations. New York, NY: Longman.

37.Ford, J. (2010). Studying leadership critically: a psychosocial lens on leadership identities. Leadership, 6(1), 47-65.

38.Friedrich, T. L., Vessey, W. B., Schuelke, M. J., Ruark, G. A., \& Mumford, M. D. (2009). A framework for understanding collective leadership: the selective utilization of leader and team expertise within networks. The Leadership Quarterly, 20(6), 933-958.

39.Fuss, I., Nübling, M., Hasselhorn, H.-M., Schwappach, D., \& Rieger, M. A. (2008). Working conditions and work-family conflict in German hospital physicians: psychosocial and organisational predictors and consequences. BMC Public Health, 8(1), 353-370.

40.Garfield, M. J., Taylor, N. J., Dennis, A. R., \& Satzinger, J. W. (2001). Modifying paradigmsindividual differences, creativity techniques, and exposure to ideas in group idea generation. Information Systems Research, 12(3), 322-333.

41.Gibb, C. A. (1954). Leadership. In G. Lindzey (Ed.), Handbook of social psychology (pp. 877-917). Reading, MA: Addison-Wesley.

42.Graham, J. R., \& Barter, K. (1999). Collaboration: a social work practice method. Families in Society: The Journal of Contemporary Social Services, 80(1), 6-13.

43.Hahn, F., Jensen, S., \& Tanev, S. (2014). Disruptive innovation vs disruptive technology: the disruptive potential of the value propositions of 3D printing technology startups. Technology Innovation Management Review, 4(12), 27-36.

44. Hauschildt, J., \& Kirchmann, E. (2001). Teamwork for innovation-the 'troika' of promotors. $R \& D$ Management, 31(1), 41-49.

45.Hendel, T., Fish, M., \& Galon, V. (2005). Leadership style and choice of strategy in conflict management among Israeli nurse managers in general hospitals. Journal of Nursing Management, 13(2), 137-146.

46. Herzog, J. (1981). Communication between co-leaders: fact or myth? A student's perspective. Social Work with Groups, 3(4), 19-29.

47.Hiller, N. J. (2001). Understanding and measuring shared leadership in work teams. Doctoral Dissertation. University Park, PA: Pennsylvania State University.

48.Hiller, N. J., Day, D. V., \& Vance, R. J. (2006). Collective enactment of leadership roles and team effectiveness: a field study. The Leadership Quarterly, 17(4), 387-397.

49.Homans, G. C. (1958). Social behavior as exchange. American Journal of Sociology, 63(6), 597-606.

50.Horwitz, S. K. (2005). The compositional impact of team diversity on performance: theoretical considerations. Human Resource Development Review, 4(2), 219-245.

51.Hu, N., Chen, Z., Gu, J., Huang, S., \& Liu, H. (2017). Conflict and creativity in inter-organizational teams: the moderating role of shared leadership. International Journal of Conflict Management, 28(1), 74102.

52.Husted, B. W., \& Allen, D. B. (2008). Toward a model of cross-cultural business ethics: the impact of individualism and collectivism on the ethical decision-making process. Journal of Business Ethics, 82(2), 293-305.

53.Inamizu, N., Fukuzawa, M., Fujimoto, T., Shintaku, J., \& Suzuki, N. (2014). Group leaders and teamwork in the over-lean production system. Journal of Organizational Change Management, 27(2), 188205.

54.Jehn, K. A. (1995). A multimethod examination of the benefits and detriments of intragroup conflict. Administrative Science Quarterly, 40(2), 256-282.

55.Jehn, K. A. (1997). A qualitative analysis of conflict types and dimensions in organizational groups. Administrative Science Quarterly, 42(3), 530-557.

56.Jehn, K. A., \& Bendersky, C. (2003). Intragroup conflict in organizations: a contingency perspective on the conflict-outcome relationship. Research in Organizational Behavior, 25, 187-242. 
57.Jehn, K. A., Chadwick, C., \& Thatcher, S. M. B. (1997). To agree or not to agree: the effects of value congruence, individual demographic dissimilarity, and conflict on workgroup outcomes. International Journal of Conflict Management, 8(4), 287-305.

58.Jehn, K. A., \& Mannix, E. A. (2001). The dynamic nature of conflict: a longitudinal study of intragroup conflict and group performance. Academy of Management Journal, 44(2), 238-251.

59.Jones, G., \& Zeitlin, J. (2008). The Oxford handbook of business history. Oxford: Oxford University Press.

60.Kaiser, U., \& Müller, B. (2013). Team heterogeneity in startups and its development over time. ZEW-Centre for European Economic Research Discussion Paper No. 13-058.

61.Kassicieh, S. U. L. (2011). Benefits from using surrogate entrepreneurs in technology commercialization. International Journal of Innovation and Technology Management, 8(4), 521-534.

62.Katz, D., \& Kahn, R. L. (1978). The social psychology of organizations. New York, NY: Wiley.

63.Kerr, S., \& Jermier, J. M. (1978). Substitutes for leadership: their meaning and measurement. Organizational Behavior and Human Performance, 22(3), 375-403.

64.Klein, K. J., Knight, A. P., Ziegert, J. C., Lim, B. C., \& Saltz, J. L. (2011). When team members' values differ: the moderating role of team leadership. Organizational Behavior and Human Decision Processes, 114(1), 25-36.

65.Knutson, T. J., Hwang, J. C., \& Deng, B. C. (2000). Perception and management of conflict: a comparison of Taiwanese and US business employees. Intercultural Communication Studies, 9(2), 1-32.

66.Kocolowski, M. D. (2010). Shared leadership: is it time for a change. Emerging Leadership Journeys, 3(1), 22-32.

67.Kohlbacher, M. (2013). The impact of dynamic capabilities through continuous improvement on innovation: the role of business process orientation. Knowledge and Process Management, 20(2), 71-76.

68.Konu, A., \& Viitanen, E. (2008). Shared leadership in Finnish social and health care. Leadership in Health Services, 21(1), 28-40.

69.Kozlowski, S. W. J., \& Bell, B. S. (2003). Work groups and teams in organizations. In W. C. Borman, \& D. R. Ilgen (Eds.), Comprehensive handbook of psychology: Industrial and organizational psychology (pp. 333-375). New York, NY: Wiley.

70.Lefebvre, E., Lefebvre, L. A., \& Talbot, S. (2000). Environmental initiatives, innovativeness and competitiveness: some empirical evidence. In Proceedings of the 2000 IEEE engineering management society. EMS-2000 (Cat. No.00CH37139) (pp. 674-679). Albuquerque, NM: IEEE.

71.Lester, C. N. (1975). Leadership styles: a key to effectiveness. Journal of Extension, 13, 3-11.

72.Li, J., Lam, K., \& Ping Fu, P. (2000). Family-oriented collectivism and its effect on firm performance: a comparison between overseas Chnese and foreign firms in China. The International Journal of Organizational Analysis, 8(4), 364-379.

73.Lim, B.-C., \& Ployhart, R. E. (2004). Transformational leadership: relations to the five-factor model and team performance in typical and maximum contexts. Journal of Applied Psychology, 89(4), 610-621.

74.Lipman-Blumen, J. (2000). Connective leadership: managing in a changing world. New York, NY: Oxford University Press.

75.Manz, C. C., \& Sims, H. P. (1980). Self-management as a substitute for leadership: a social learning theory perspective. Academy of Management Review, 5(3), 361-367.

76.Martínez-Moreno, E., González-Navarro, P., Zornoza, A., \& Ripoll, P. (2009). Relationship, task and process conflicts on team performance: the moderating role of communication media. International Journal of Conflict Management, 20(3), 251-268.

77.Martini, A., Laugen, B. T., Gastaldi, L., \& Corso, M. (2013). Continuous innovation: towards a paradoxical, ambidextrous combination of exploration and exploitation. International Journal of Technology Management, 61(1), 1-22.

78.Mattila, A. S., \& Patterson, P. G. (2004). Service recovery and fairness perceptions in collectivist and individualist contexts. Journal of Service Research, 6(4), 336-346.

79. Mayo, E. (1993). The human problems of an industrial civilization. New York, NY: MacMillan.

80.Mehra, A., Smith, B. R., Dixon, A. L., \& Robertson, B. (2006). Distributed leadership in teams: the network of leadership perceptions and team performance. The Leadership Quarterly, 17(3), 232-245. 
81.Meyers, R. A., \& Johnson, J. R. (2008). Facilitating the design of a campus leadership team. Communication Education, 57(4), 472-481.

82.Millikin, J. P., Hom, P. W., \& Manz, C. C. (2010). Self-management competencies in self-managing teams: their impact on multi-team system productivity. The Leadership Quarterly, 21(5), 687-702.

83.Mintz, E. E. (1963). Transference in co-therapy groups. Journal of Consulting Psychology, 27(1), 34-39.

84.Mohammed, S., \& Nadkarni, S. (2011). Temporal diversity and team performance: the moderating role of team temporal leadership. Academy of Management Journal, 54(3), 489-508.

85.Pânzaru, S. (2014). Teamwork-guarantee of managerial success. Review of General Management, 20(2), 150-158.

86.Passos, A. M., \& Caetano, A. (2005). Exploring the effects of intragroup conflict and past performance feedback on team effectiveness. Journal of Managerial Psychology, 20(3/4), 231-244.

87.Pearce, C. L., \& Conger, J. A. (2002). Shared leadership: reframing the hows and whys of leadership. Thousand Oaks, CA: Sage.

88.Pearce, C. L., \& Conger, J. A. (2003). Shared leadership: reframing the hows and whys of leadership. Thousand Oaks, CA: Sage.

89.Pearce, C. L., Manz, C. C., \& Sims, H. P. (2009). Where do we go from here?: Is shared leadership the key to team success? Organizational Dynamics, 38(3), 234-238.

90.Pearce, C. L., \& Sims, H. P., Jr. (2002). Vertical versus shared leadership as predictors of the effectiveness of change management teams: an examination of aversive, directive, transactional, transformational, and empowering leader behaviors. Group Dynamics: Theory, Research, and Practice, 6(2), 172-197.

91.Pearce, C. L., Yoo, Y., \& Alavi, M. (2004). Leadership, social work and virtual teams: the relative influence of vertical vs. shared leadership in the nonprofit sector. In R. E. Riggio, \& S. Smith-Orr (Eds.), Improving leadership in nonprofit organizations (pp. 180-203). San Francisco: Jossey-Bass.

92.Perry, M. L., Pearce, C. L., \& Sims, H. P. (1999). Empowered selling teams: how shared leadership can contribute to selling team outcomes. The Journal of Personal Selling and Sales Management, 19(3), 3551.

93.Porter-O'Grady, T., \& Wilson, C. K. (1995). The leadership revolution in health care: altering systems, changing behaviors. Gaithersburg, MD: Aspen Publishers, Inc.

94.Powell, S. G. (2000). Specialization, teamwork, and production efficiency. International Journal of Production Economics, 67(3), 205-218.

95.Prati, L. M., Douglas, C., Ferris, G. R., Ammeter, A. P., \& Buckley, M. R. (2003). Emotional intelligence, leadership effectiveness, and team outcomes. The International Journal of Organizational Analysis, 11(1), 21-40.

96.Rice, N. (2006). Opportunities lost, possibilities found: shared leadership and inclusion in an urban high school. Journal of Disability Policy Studies, 17(2), 88-100.

97.Rittner, B., \& Hammons, K. (1993). Telephone group work with people with end stage AIDS. Social Work With Groups, 15(4), 59-72.

98.Schaeffner, M., Huettermann, H., Gebert, D., Boerner, S., Kearney, E., \& Song, L. J. (2015). Swim or sink together: the potential of collective team identification and team member alignment for separating task and relationship conflicts. Group \& Organization Management, 40(4), 467-499.

99.Shah, P. P., \& Jehn, K. A. (1993). Do friends perform better than acquaintances? The interaction of friendship, conflict, and task. Group Decision and Negotiation, 2(2), 149-165.

100. Sharma, N. (2015). Funding of innovative start-ups in India. Available at https://ssrn.com/abstract=2647598 or http://dx.doi.org/10.2139/ssrn.2647598.

101. Shenkar, O., \& Ronen, S. (1987). The cultural context of negotiations: the implications of Chinese interpersonal norms. The Journal of Psychology, 44, 491-504.

102. Simons, T., Pelled, L. H., \& Smith, K. A. (1999). Making use of difference: diversity, debate, and decision comprehensiveness in top management teams. Academy of Management Journal, 42(6), 662-673.

103. Simons, T. L., \& Peterson, R. S. (2000). Task conflict and relationship conflict in top management teams: the pivotal role of intragroup trust. Journal of Applied Psychology, 85(1), 102-111. 
104. Sivasubramaniam, N., Murry, W. D., Avolio, B. J., \& Jung, D. I. (2002). A longitudinal model of the effects of team leadership and group potency on group performance. Group \& Organization Management, 27(1), 66-96.

105. Solomon, A., Loeffler, F. J., \& Frank, G. H. (1953). An analysis of co-therapist interaction in group psychotherapy. International Journal of Group Psychotherapy, 3(2), 171-180.

106. Somech, A. (2006). The effects of leadership style and team process on performance and innovation in functionally heterogeneous teams. Journal of Management, 32(1), 132-157.

107. Steinert, T., Goebel, R., \& Rieger, W. (2006). A nurse-physician co-leadership model in psychiatric hospitals: results of a survey among leading staff members in three sites. International Journal of Mental Health Nursing, 15(4), 251-257.

108. Steinheider, B., \& Wuestewald, T. (2008). From the bottom-up: sharing leadership in a police agency. Police Practice and Research, 9(2), 145-163.

109. Storey, J. (2004). Leadership in organizations: current issues and key trends. London: Psychology Press.

110. Tidd, S. T., McIntyre, H. H., \& Friedman, R. A. (2004). The importance of role ambiguity and trust in conflict perception: unpacking the task conflict to relationship conflict linkage. International Journal of Conflict Management, 15(4), 364-380.

111. Tjosvold, D. (1991). The conflict-positive organization. Boston, MA: Addison Wesley.

112. Tjosvold, D. (2008). The conflict-positive organization: it depends upon us. Journal of Organizational Behavior, 29(1), 19-28.

113. Tse, D. K., Francis, J., \& Walls, J. (1994). Cultural differences in conducting intra- and intercultural negotiations: a Sino-Canadian comparison. Journal of International Business Studies, 25(3), 537555.

114. Tyler, T. R., \& Blader, S. L. (2003). The group engagement model: procedural justice, social identity, and cooperative behavior. Personality and Social Psychology Review, 7(4), 349-361.

115. Ulijn, J., Aaltio, I., Guerra, G., \& Uhlaner, L. (2011). Cooperation and teamwork in technology start-ups: reflected in some Italian, British, Dutch and German findings. International Journal of Entrepreneurship and Small Business, 14(1), 100-126.

116. van Hove, J. (2018). Research on technology entrepreneurship and accelerators. Doctoral Dissertation. Ghent: Ghent University.

117. Vancouver, J. B. (2000). Self-regulation in organizational settings: a tale of two paradigms. In M. Boekaerts, P. R. Pintrich, \& M. Zeidner (Eds.), Handbook of self-regulation (pp. 303-336). San Diego, CA: Academic Press.

118. Vroom, V. H., \& Yetton, P. W. (1973). Leadership and decision-making. Pittsburgh: University of Pittsburgh Press.

119. Wageman, R. (1997). Critical success factors for creating superb self-managing teams. Organizational Dynamics, 26(1), 49-61.

120. Walker, A. G., Smither, J. W., \& Waldman, D. A. (2008). A longitudinal examination of concomitant changes in team leadership and customer satisfaction. Personnel Psychology, 61(3), 547-577.

121. Wang, D., Waldman, D. A., \& Zhang, Z. (2014). A meta-analysis of shared leadership and team effectiveness. Journal of Applied Psychology, 99(2), 181-198.

122. Weldon, E., Jehn, K. A., Doucet, L., Chen, X., \& Wang, Z. M. (1996). Conflict management in USChinese joint ventures. Management Issues in China, 2, 89-105.

123. Westwood, R. I., Tang, S. F. Y., \& Kirkbride, P. S. (1992). Chinese conflict behavior: cultural antecedents and behavioral consequences. Organization Development Journal, 10, 13-19.

124. Wood, M. S. (2005). Determinants of shared leadership in management teams. International Journal of Leadership Studies, 1(1), 64-85.

125. Wood, M. S., \& Fields, D. (2007). Exploring the impact of shared leadership on management team member job outcomes. Baltic Journal of Management, 2(3), 251-272.
126. Yıldız
Kuluçka.
(2018).
Firms (In
Turkish).
Avaliable
at

https://www.yildizkulucka.com/firmalar/c/295 (accessed 16.07.2019). 
127. Zaccaro, S. J., Heinen, B., \& Shuffler, M. (2009). Team leadership and team effectiveness. In E. Salas, G. F. Goodwin, \& C. S. Burke (Eds.), The organizational frontiers series. Team effectiveness in complex organizations: cross-disciplinary perspectives and approaches (pp. 83-111). New York, NY: Routledge/Taylor \& Francis Group.

128. Zaccaro, S. J., Rittman, A. L., \& Marks, M. A. (2001). Team leadership. The Leadership Quarterly, 12(4), 451-483.

129. Zairi, M. (1997). Business process management: a boundaryless approach to modern competitiveness. Business Process Management Journal, 3(1), 64-80. 